\title{
The enterprising manager and project performance
}

Rosária de Fatima Segger Macri Russo and Roberto Sbragia

Faculty of Economics, Business Administration and Accountancy of the University of São Paulo (FEA/USP), Brazil

\begin{abstract}
Project managers can play a key role in implementing organizational strategy by using entrepreneurial approaches when responding to new needs and opportunities. Nevertheless, the operational responsibilities of a project manager - planning and control - are in stark contrast to the characteristics of an entrepreneur. In light of these contradictory viewpoints, it is important to assess whether managers showing entrepreneurial characteristics are associated with more successful projects. A field survey was conducted, involving 164 project managers most of whom were male and had graduate-level education and broad practical business experience. Non-parametric statistics was used and showed that enterprising tendency on the part of project managers is correlated with more successful projects, and creativity, in particular, was one of the most relevant variables.
\end{abstract}

Keywords: project manager; corporate entrepreneurship; project success; enterprising tendency; creativity

\section{Introduction}

There comes a point in the path of every business venture where the "founding entrepreneur" figure, upon whom all rely as the main source of innovation, can no longer be considered sufficient to ensure organizational growth and survival. Employees and partners who are active in the organization's structure must also contribute to the search for innovation (Birley \& Muzyka 2001: 285). As early as the 1940s, Schumpeter (1949: 71) noted that a single individual could not embody the entrepreneurship function; it must be exercised cooperatively. A simple idea evolves through the contributions of those with different points of view - such as personnel from different departments - leading to new products, new services, or even new businesses.

Encouraging employees to be entrepreneurial within the organizational structure they work in, by providing them with the freedom and resources they need to pursue their visions, is one of the best ways of ensuring innovation (Pinchot III 1989). Many authors have referred to such an enterprising employee as the corporate entrepreneur (Luchsinger \& Bagby 1987; Lumpkin \& Dess 1996); others have used the term intrapreneur to describe them (Hashimoto 2006; Pinchot III 1989). However, according to Andreassi (2005), one must distinguish corporate entrepreneurship, or venturing, from intrapreneurship. The former concept relates to the process whereby a new business is created within an existing organization. Intrapreneurship, on the other hand, is the quality of a certain individual, regardless of hierarchy or position, who has a sense of opportunity, is sensitive to the challenges and issues faced by his or her employer, and is obstinately committed to solving these issues. The present study will focus on intrapreneurship as defined above, but the generic term entrepreneurship is used.

One figure currently in the organizational spotlight when it comes to employee entrepreneurship is that of the project manager. On the one hand, he or she may be considered 
critical to the future of an organization because their proximity to the external environment customers, suppliers, partners, competitors - places them in an ideal position to identify untapped needs and opportunities by using any entrepreneurial skills they may have. They are also a key element in implementing corporate strategy, not least because changes in strategic direction are commonly accomplished through new projects. On the other hand, their position is traditionally known for its operational responsibilities - planning, monitoring, and control - which are meant to ensure that project goals (particularly those concerning costs and deadlines) are met. Entrepreneurial characteristics may not be necessary for the proper performance of this traditional role, which gives rise to a certain amount of contradiction.

Given the importance of entrepreneurship as well as that of the project manager function in how companies adapt to needs for innovation, and both external (demand pull) and internal (technology push), it appears that an assessment of whether entrepreneurial traits add value to project managers by leading to greater project success is in order. This is the main objective of the present study.

The next section will provide a theoretical review of the key concepts behind the study, particularly those concerning entrepreneurship, project performance, and the project manager. This will be followed by a description of the methods used, and the analysis and interpretation of the data. Finally, the conclusions and a few recommendations will be presented.

\section{Conceptual framework}

\section{Entrepreneurship}

Entrepreneurship may be defined as the process through which something new and valuable is created through the dedication and effort of someone who takes on financial, psychological, and social risks and seeks personal satisfaction and monetary rewards (Hisrich $\&$ Peters 1986). Pinpointing the characteristics of an entrepreneur is a complex task, and has been the object of considerable study (Antoncic \& Hisrich 2001; Carland et al. 1984; Cohen \& Grahan 2002; Cunningham and Lischeron 1991; Pinchot III 1989; Stopford \& BadenFuller 1994).

Caird (1991: 179) presented a breakdown of significant enterprising characteristics attributed to entrepreneurs into five dimensions and showed that entrepreneurs (business owners) scored higher in all five. The dimensions and the qualities associated with them were defined as follows:

-Need for achievement: oriented towards the future, relies on own ability, has an optimistic outlook, strongly task- and result-oriented, restless and energetic, self-confident and opinionated, persistent, determined, and is dedicated and willing to work hard to complete tasks;

-Need for autonomy/independence: is unconventional, prefers working alone, strongly opinionated (must say what they think and make up their own mind), prefers to be in charge and dislikes taking orders, and is unresponsive to group pressure;

-Creative tendency: is imaginative and innovative, intuitive (a dreamer), versatile and able to draw on experience for problem solving, comes up with many new ideas, and prefers novelty, change, and challenges to routines; 
-Calculated risk taking: is able to act on incomplete information and judge when incomplete information is sufficient for action, self-aware and able to accurately assess their own capabilities, adequately ambitious, good at evaluating cost and benefit, and set themselves challenging but attainable goals;

-Internal locus of control: takes advantage of opportunities, does not believe in or accept being controlled by fate, is self-confident and takes personal responsibility for his or her destiny, equates results achieved with effort made, and is strong-willed and determined.

The dimensions identified by Lumpkin and Dess (1996: 140), complemented the above dimensions (enterprising tendency), but take a more organizational stance: autonomy, innovativeness, risk taking, being proactive, and competitive aggressiveness. The authors also note the difficulty of characterizing the entrepreneurial figure, stating that these dimensions may vary independently of one another in a given context.

\section{Projects and success}

All organizations have strategies in place to direct activities meant to leverage and ensure survival of the business, seeking results that are satisfactory not only to shareholders, but also to stakeholders. Most of these strategies are implemented through projects, which may be defined as temporary efforts to create a product, service, or exclusive result. Due to their intrinsic characteristics of temporality, novelty, and uniqueness, all projects carry a certain degree of innovation. Such innovation leads to greater difficulty in execution, meaning that many projects will not be entirely successful, and some may fail outright.

In their retrospective study of the understanding of "project success", Jugdev and Müller (2005: 23), as shown in Figure 1, present the evolution of this concept within the product lifecycle. This evolution in meaning of project success has changed the manner in which projects are managed, as the goals to be met - and the expectations resulting from their being met - have also changed over time. Kerzner (2003: 43) notes that in the 1960s, considered the first period in which there was a concern with project success, this was measured solely in technical terms - i.e., a project was deemed successful if the product it created was adequate to the producing organization.

PRODUCT LIFE CYCLE

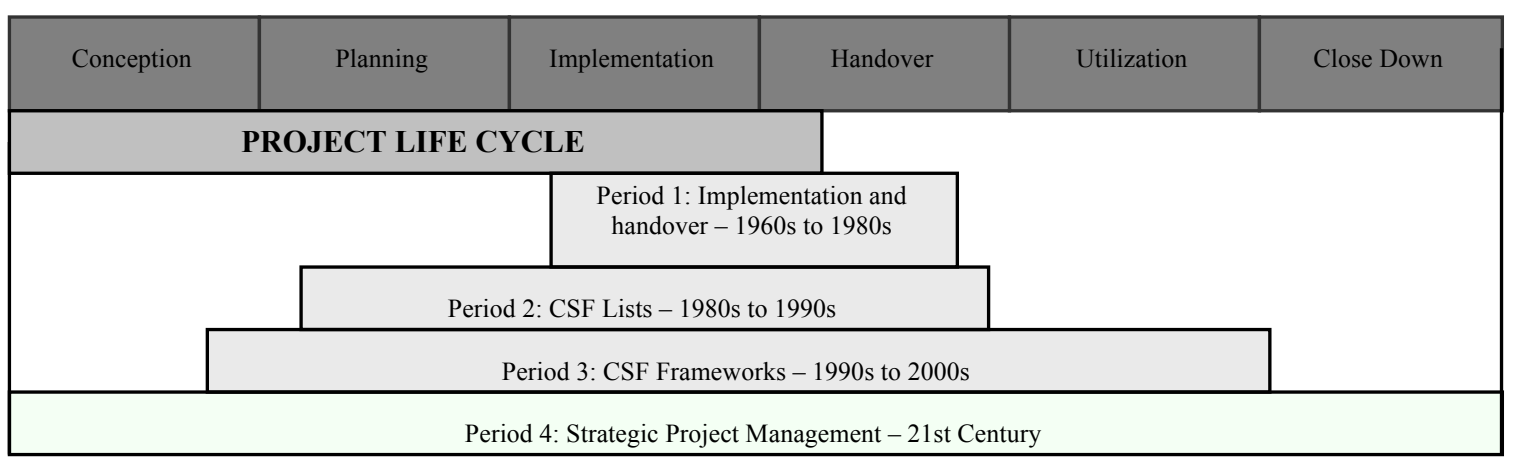

Figure 1 - Evolution of project success measurement over time

Source: Adapted from Jugdev and Müller 2005. 
During the 1980s and 1990s - Period Two of project management - numerous works presented examples of successful projects and lessons to be learned from failed ones, such as Cleland (1999: 200): failure to understand project complexity; internal communication breakdowns; ineffective project strategy; overdependence on software; poor education and training; lack of commitment from leaders and sponsors. These factors eventually became known as Critical Success Factors (CSF).

The early Third Period of project management (1990s to 2000s) saw the development of certain frameworks for CFS, meant to assess several criteria and comprising factors external as well as internal to the project-initiating organization. In line with this evolution, the meaning of project success also changed, to become broader (Pinto \& Slevin 1988; Sbragia, Maximiano \& Kruglianskas 1986). In recognition of the fact that different people will have different perceptions of "success" and that this perception will vary over time, Shenhar, Levy and Dvir (1997: 5) developed a study based on the following four dimensions:

-Project efficiency: analyzes whether the project met deadlines and budget objectives. Some organizations may add indicators specific to their sector to this dimension, such as the number of changes made to the product before its market launch;

-Impact on customer: related to the customer and/or end-user's requirements and needs, and on whether they were met. Also concerns customer satisfaction with project and how much the customer would be interested in an extension to the project;

- Business success: assesses project impact on the organization, such as contribution to current profit, how many deals were leveraged by the project, or whether the project led to a short-term increase in market share;

-Preparing for the future: assesses the extent to which the project helped prepare company infrastructure for the future, enabling creation of a new market for company, new product line, or new technology.

In Period 4, studies showed that project success does not only mean successful completion of a project, but also choosing the most appropriate project in the strategic context of the organization. A recurring theme in optimal project selection is the categorization and prioritization of projects within a portfolio that, besides meeting strategic goals, will also maximize return on investment (Crawford, Hobbs \& Turner 2006: 46). This complementary approach has helped organizations develop and designate appropriate, specific competencies required for a project to be carried out successfully.

\section{The project manager}

Although accountability for the performance and outcome of a project is usually assigned to the team as a whole, primary responsibility is always incumbent upon the project manager. Besides knowing project goals and expectations and making them clear to all those involved in its execution, the project manager must ensure that these goals and expectations are met, through basic management of time, cost, scope, communication, human resources, contracts, material, and risk (Dinsmore 1993: 40).

In order to play this role successfully, a manager must possess certain characteristics. Table 1 presents those that were cited most often in a review of the project management literature. 
Entrepreneurship was mentioned only by Kerzner (2001), who notes it explicitly, and by Cohen and Graham (2002) and Dinsmore (1992), who cite treating the project as a business venture and looking beyond the company as desired characteristics.

One point where the roles of entrepreneur and project manager diverge is that the latter is expected to be "daring when it comes to finding the best solutions for problems faced by the enterprise" (Rabechini Jr. 2005: 70). However, one of the tenets of project management is that the manager is expected, above all, to stay within the defined scope of the project (PMI 2004: 103). This traditional view appears to preclude any expectations that a project manager should have enterprising tendencies, but instead expects them to be able to accurately and precisely plan for what has been defined initially and to carry out this plan to the best possible outcome. The present study seeks to clarify this contradiction.

\section{Methods}

It was sought to investigate the presence of entrepreneurial characteristics in the profile of project managers and their influence on the success of project outcomes, through descriptive, quantitative research. To that end, a cross-sectional e-survey was carried out (Selltiz et al. 1987: 49).

The survey was conducted online due to various advantages, particularly the possibility of fast, automatic data transfer and tabulation and the fact that e-surveys are far more practical for respondents than those conducted through traditional means. Nevertheless, these advantages must be weighed against a variety of drawbacks, such as lower response rates compared to those obtained in conventional surveys, a greater concern with instrument and response database structure, a certain difficulty in ensuring the accuracy of respondents' email addresses, and difficulty controlling the conditions under which respondents take the survey (Vasconcellos \& Guedes 2007).

In defining the characteristics of an entrepreneur, the five dimensions described by Caird (1991: 179) were used, with one of them (Internal Locus of Control) being called Drive and Determination in the present study but with the same meaning. These dimensions were assessed through the General Enterprising Tendency (GET) test, courtesy of the Durham University Business School, which holds copyright to the GET. The GET uses a unique methodology to analyze enterprising tendency. Each of its 54 items represents an entrepreneurial "style" or "attitude"; respondents are asked whether they agree or disagree with each one. Every item is related to a studied dimension (six are related to Need for autonomy and 12 are related to each of the other dimensions). A respondent is identified as possessing a given dimension on the GET if he or she reaches a minimum number of points in the test (nine points for Need for achievement, four points for Need for autonomy, and eight points for each of the other dimensions). With this information, it an independent variable called the Project Manager Enterprising Tendency Level was developed, which varied according to the number of dimensions found in each manager, on a scale of "very low" (one or no dimensions) to "very high" (all five dimensions). 
Table 1. Project manager characteristics cited most often in the literature

\begin{tabular}{|c|c|c|c|}
\hline Dimension & Characteristic & Citations & Cited by \\
\hline \multirow{5}{*}{$\begin{array}{l}\text { Technical / } \\
\text { administrative } \\
\text { competence }\end{array}$} & Administrative competence & 3 & Dinsmore, 1992; Kerzner, 2001; Meredith and Mantel Jr., 2003 \\
\hline & Technical competence & 5 & $\begin{array}{l}\text { Archibald, 2003; Dinsmore, 1992; Kerzner, 2001; Meredith and } \\
\text { Mantel Jr., 2003; Rabechini Jr., } 2005\end{array}$ \\
\hline & Technology Knowledge & 3 & $\begin{array}{l}\text { Archibald, 2003; Crawford and Cabanis-Brewin, 2006; Dinsmore, } \\
1992\end{array}$ \\
\hline & Project knowledge & 3 & $\begin{array}{l}\text { Archibald, 2003; Crawford and Cabanis-Brewin, 2006; Dinsmore, } \\
1992\end{array}$ \\
\hline & Organization & 3 & Archibald, 2003; Heldman, 2003; Kerzner, 2001 \\
\hline $\begin{array}{l}\text { Communication } \\
\text { skills }\end{array}$ & Communication skills & 6 & $\begin{array}{l}\text { Archibald, 2003; Crawford and Cabanis-Brewin, 2006; Dinsmore, } \\
\text { 1992; Heldman, 2003; Rabechini Jr., 2005; Verma, } 1996\end{array}$ \\
\hline \multirow{3}{*}{$\begin{array}{l}\text { Organizational } \\
\text { awareness }\end{array}$} & Organizational commitment & 2 & Dinsmore, 1992; PMI, 2002 \\
\hline & Organizational awareness & 2 & Dinsmore, 1992; PMI, 2002 \\
\hline & Political sensitivity & 2 & Meredith and Mantel Jr., 2003; Verma, 1996 \\
\hline $\begin{array}{l}\text { Stress } \\
\text { management }\end{array}$ & Stress management & 2 & Meredith and Mantel Jr., 2003; Verma, 1996 \\
\hline \multirow[b]{2}{*}{ Leadership } & Impact and influence & 3 & Heldman, 2003; PMI, 2002; Verma, 1996 \\
\hline & Leadership & 9 & $\begin{array}{l}\text { Archibald, 2003; Crawford and Cabanis-Brewin, 2006; Dinsmore, } \\
\text { 1992; Heldman, 2003; Kerzner, 2001; Meredith and Mantel Jr., } \\
\text { 2003; PMI, 2002; Rabechini Jr., 2005; Verma, } 1996\end{array}$ \\
\hline Risk measurement & Risk measurement & 2 & Cohen and Graham, 2002; Dinsmore, 1992 \\
\hline \multirow{2}{*}{ Negotiating skills } & Conflict management & 5 & $\begin{array}{l}\text { Dinsmore, 1992; Kerzner, 2001; Meredith and Mantel Jr., 2003; } \\
\text { Rabechini Jr., 2005; Verma, } 1996\end{array}$ \\
\hline & Negotiation & 4 & $\begin{array}{l}\text { Crawford and Cabanis-Brewin, 2006; Heldman, 2003; Rabechini } \\
\text { Jr., 2005; Verma, } 1996\end{array}$ \\
\hline \multirow{5}{*}{$\begin{array}{l}\text { Accomplishment- } \\
\text { oriented }\end{array}$} & Information seeking & 1 & PMI, 2002 \\
\hline & Personal initiative & 2 & Archibald, 2003; PMI, 2002 \\
\hline & Accomplishment-oriented & 2 & Crawford and Cabanis-Brewin, 2006; PMI, 2002 \\
\hline & Concerned with order & 1 & PMI, 2002 \\
\hline & Problem-solving & 3 & $\begin{array}{l}\text { Archibald, 2003; Crawford and Cabanis-Brewin, 2006; Heldman, } \\
2003\end{array}$ \\
\hline $\begin{array}{l}\text { Customer service- } \\
\text { oriented }\end{array}$ & Customer service-oriented & 2 & PMI, 2002; Rabechini Jr., 2005 \\
\hline \multirow{3}{*}{ Planning skills } & Budget planning & 1 & Heldman, 2003 \\
\hline & Planning and control skills & 1 & Archibald, 2003 \\
\hline & Planning & 3 & Dinsmore, 1992; Heldman, 2003; Kerzner, 2001 \\
\hline \multirow{5}{*}{ HR skills } & Relationship building & 3 & Dinsmore, 1992; PMI, 2002; Rabechini Jr., 2005 \\
\hline & Personnel development & 1 & PMI, 2002 \\
\hline & Empathy & 1 & PMI, 2002 \\
\hline & HR management & 1 & Heldman, 2003 \\
\hline & Relationship skills & 2 & Heldman, 2003; Rabechini Jr., 2005 \\
\hline \multirow{3}{*}{ Teamwork } & Resource allocation & 1 & Kerzner, 2001 \\
\hline & Team building & 3 & Dinsmore, 1992; Heldman, 2003; Kerzner, 2001 \\
\hline & Cooperation and team spirit & 1 & PMI, 2002 \\
\hline \multirow{4}{*}{$\begin{array}{l}\text { Approaches } \\
\text { project as if it } \\
\text { were a business } \\
\text { venture }\end{array}$} & New business development & 1 & Dinsmore, 1992 \\
\hline & Entrepreneurship & 1 & Kerzner, 2001 \\
\hline & $\begin{array}{l}\text { Treats project as would a } \\
\text { business venture }\end{array}$ & 2 & Cohen and Graham, 2002; Dinsmore, 1992 \\
\hline & $\begin{array}{l}\text { Sees the big picture (aware of } \\
\text { markets, groups, people) }\end{array}$ & 2 & Cohen and Graham, 2002; Dinsmore, 1992 \\
\hline \multirow{4}{*}{ Personal skills } & Self-confidence & 2 & Crawford and Cabanis-Brewin, 2006; PMI, 2002 \\
\hline & Self-control & 2 & Crawford and Cabanis-Brewin, 2006; PMI, 2002 \\
\hline & Flexibility & 2 & Archibald, 2003; PMI, 2002 \\
\hline & Motivation & 1 & Verma, 1996 \\
\hline
\end{tabular}


The four-dimension model proposed by Shenhar, Levy and Dvir (1997: 5) was used as a tool to evaluate project success, with one added criteria - impact on team, i.e., the degree of team satisfaction at the end of the project. Thus, the study's dependent variable, Project Success Level, was generated from a set of ten criteria: project met technical specifications; project met functional specifications; project met deadlines; project complied with budget constraints; project met client needs; project solved at least one major operational issue or problem; end product used by client; client satisfied with delivered product; end product had a positive impact on organizational performance; and team satisfaction at the end of the project. The K-means algorithm (Malhotra 2001: 531) was used to cluster projects into two groups: projects with less successful outcomes (48 cases, 30\% of sample) and those that were more successful (116 cases, $70 \%$ of sample). Although originally proposed (Table 2 ), there were seven other success criteria that were not used in this cluster due to the low number of valid responses: product made commercial success; increase in organization market share; cost reduction in organization, new market creation for organization; new product line; new technology; and new competency in organization.

Table 2. Correlation between dimensions of enterprising tendency and project success criteria

\begin{tabular}{|c|c|c|c|c|c|c|c|}
\hline \multirow[b]{2}{*}{$\begin{array}{l}\text { Project } \\
\text { Success } \\
\text { Dimension }\end{array}$} & \multirow[b]{2}{*}{ Success Criteria } & \multirow[b]{2}{*}{$\mathrm{N}$} & \multicolumn{5}{|c|}{ Enterprising Tendency Dimension } \\
\hline & & & $\begin{array}{l}\text { Achieve- } \\
\text { ment }\end{array}$ & $\begin{array}{l}\text { Auto- } \\
\text { nomy }\end{array}$ & $\begin{array}{l}\text { Creative } \\
\text { Tendency }\end{array}$ & $\begin{array}{l}\text { Risk } \\
\text { Taking }\end{array}$ & $\begin{array}{l}\text { Drive and } \\
\text { Deter- } \\
\text { mination }\end{array}$ \\
\hline Project & Deadline & 164 & 0.153 & -0.035 & $.172(*)$ & 0.087 & 0.129 \\
\hline Efficiency & Cost & 164 & $.180(*)$ & 0.04 & $.166(*)$ & 0.14 & 0.112 \\
\hline \multirow{6}{*}{$\begin{array}{l}\text { Impact on } \\
\text { customer }\end{array}$} & $\begin{array}{l}\text { Technical } \\
\text { specifications }\end{array}$ & 164 & 0.013 & -0.116 & 0.126 & 0.001 & 0.089 \\
\hline & $\begin{array}{l}\text { Functional } \\
\text { specifications }\end{array}$ & 164 & 0.078 & -0.113 & $.163(*)$ & 0.075 & 0.103 \\
\hline & Client needs & 164 & 0.092 & -0.12 & $.289(* *)$ & 0.131 & 0.087 \\
\hline & $\begin{array}{l}\text { Addresses most } \\
\text { important issue }\end{array}$ & 164 & 0.004 & -0.152 & 0.125 & 0.057 & -0.025 \\
\hline & Current use & 164 & 0.014 & -0.146 & $.205(* *)$ & 0.1 & -0.022 \\
\hline & End product & 164 & 0.059 & -0.125 & $.207(* *)$ & $.171(*)$ & 0.024 \\
\hline \multirow{4}{*}{$\begin{array}{l}\text { Direct } \\
\text { impact on } \\
\text { business } \\
\text { success }\end{array}$} & Organiz. performance & 164 & -0.034 & $-.196(*)$ & $.158(*)$ & 0.137 & -0.027 \\
\hline & Commercial success & 112 & 0.022 &,- 0.144 & $.191(*)$ & 0.129 & 0.01 \\
\hline & $\begin{array}{l}\text { Increase in market } \\
\text { share }\end{array}$ & 112 & 0.001 & -0.084 & 0.089 & 0.108 & -0.111 \\
\hline & Cost reduction & 120 & -0.004 & -0.071 & 0.033 & -0.034 & -0.152 \\
\hline \multirow{4}{*}{$\begin{array}{l}\text { Preparing } \\
\text { for the } \\
\text { future }\end{array}$} & $\begin{array}{l}\text { New market for } \\
\text { organization }\end{array}$ & 93 & 0.112 & 0.007 & $.217(*)$ & 0.131 & 0.025 \\
\hline & New product line & 101 & 0.059 & -0.038 & 0.187 & 0.125 & 0.009 \\
\hline & New technology & 115 & 0.016 & -0.073 & 0.112 & 0.118 & 0.062 \\
\hline & New competency & 131 & 0.124 & -0.042 & 0.042 & 0.054 & -0.062 \\
\hline $\begin{array}{l}\text { Team } \\
\text { impact }\end{array}$ & Team satisfaction & 164 & 0.09 & -0.101 & $.192(*)$ & 0.085 & 0.045 \\
\hline \multicolumn{2}{|c|}{ Project Success Level } & 164 & 0.099 & -0.076 & $.157(*)$ & 0.106 & 0.1 \\
\hline
\end{tabular}

* Correlation is significant for an $\alpha$-level of 5\% (according to Spearman's rank correlation coefficient)

** Correlation is significant for an $\alpha$-level of $1 \%$ (according to Spearman's coefficient). 


\section{Sample and respondents}

The subject population chosen for this study was drawn from the professional registry of the Project Management Institute (PMI) São Paulo Chapter. An invite was forwarded to approximately 12,000 project managers, $35 \%$ of whom had incorrect addresses listed. The questionnaire was available online from 10 October through 30 November 2006, and was answered by 313 managers $(2.24 \%$ of sample). The sample must therefore be considered a non-probability one, as it comprised only project managers who were willing to respond to the survey. Of the 313 responses, only 164 (1.06\% of sample) were considered valid. Two limitations clearly result from this procedure. The first concerns what we may infer from results. A non-probability sample and lack of control over non-respondents precludes generalization of results to a broader population. The second limitation concerns respondents. Ideally, different study variables would have been evaluated by different people; the GET test, however, requires that responses be provided by none other than the project manager, even though clients would certainly provide a more appropriate (and less positively biased) assessment of certain project success criteria. May be questionnaires were affected by respondent bias, as $70 \%$ of projects were considered as having a successful outcome. Nonetheless, all studies are subject to time, cost, and accessibility constraints. Although the presence of additional, perhaps more adequate, respondents could have changed study results, the use of data from people close to the studied phenomenon (e.g. a project manager in a study of project outcomes, as was the case here) is a perfectly acceptable procedure widely used in the social sciences (Selltiz et al., 1987), with the proviso that results must always be treated as the product of respondents' viewpoints.

Most organizations behind studied projects were private (92\%), Brazilian-owned (62\%), large corporations $(70 \%)$ operating in the service sector $(76 \%)$. Our respondents were mostly male $(78 \%)$, with a strong educational background ( $72 \%$ had a graduate or postgraduate education), and were over the age of $32(68 \%)$. In general, they had a considerable body of professional knowledge: 54\% of them had over 15 years' experience in their field.

\section{Data analysis}

Data analysis was conducted through non-parametric statistics. This is considered appropriate in situations where a standard distribution of variables cannot be ensured (Pestana \& Gageiro 2000: 145). Initially the Mann-Whitney-Wilcoxon test (Mann-Whitney U) was used to ascertain the significance of the association between a manager's enterprising tendency and project success level. The Mann-Whitney $U$ is considered the most powerful non-parametric test for large sample sizes (Siegel and Castellan Jr 2006: 177). Correlations that were more specific were also analyzed through Spearman's rank correlation coefficient, all at a significance level of $5 \%$.

\section{Analysis and discussion of results}

The statistical analyses began by considering the distribution of successful ( $70 \%$ of total) and less successful (30\%) projects for each enterprising tendency level, as shown in Figure 2. A marked increase in the ratio of successful to unsuccessful projects was found as manager entrepreneurial tendency increased (from a roughly 40:60 ratio to 90:10), suggesting a positive correlation between manager enterprising tendency and project success level. 


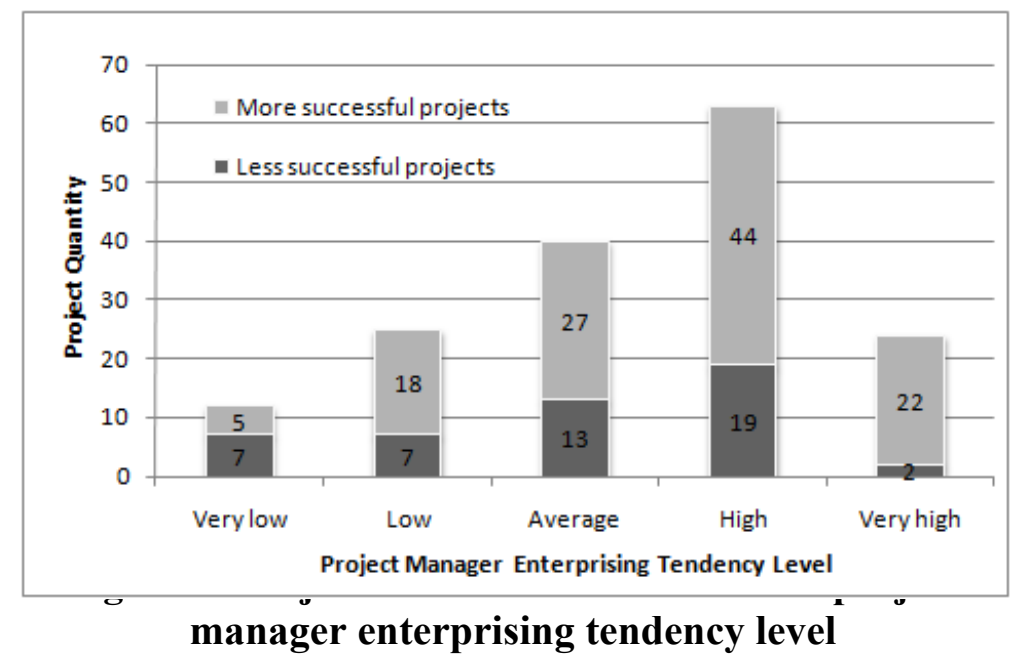

Mann-Whitney $U$ testing found the correlation significant at the $2 \%$ level, providing statistical confirmation that the greater a project manager's enterprising tendency, the greater the likelihood of his or her projects having a successful outcome.

The correlation of each dimension of enterprising tendency with each of the project success

criteria was then analyzed, as shown in Table 2. The level of correlation between Need for achievement and compliance with budget constraints suggests it plays a strong role in the expectations of project managers. This dimension was present in $77 \%$ of cases.

The Need for autonomy dimension, one of those least seen in project managers (30\%), was found to be both statistically significant and negatively correlated with project impact on organizational performance. This may suggest that the respondents would have trouble seeing the broader significance of a project to the company as a whole, as opposed to its implications in areas or departments closer to the manager's work environment. This finding may also be explained by the fact that many project managers work their way up from technical positions, which usually feature a high degree of autonomy and attachment to one's personal work achievements (Medcof 1985).

Despite being found in only $62 \%$ of respondents, the Creative tendency dimension was markedly and positively correlated with 10 out of 17 project success criteria, as well as with global Project Success Level. Interestingly, it was the only dimension not cited in the literature as a characteristic of project managers. Creative tendency was correlated, even if weakly, with success factors in all dimensions: project efficiency, impact on customer, impact on business success, and preparing for the future. This finding clearly indicates that further study of creative tendency in project managers and its effect on project outcomes is in order.

The Risk taking dimension, found in $75 \%$ of cases, was positively correlated with client satisfaction with delivered product. Project managers' ability to act on incomplete information and face challenges likely led to the development of products that met or even exceeded client expectations. This may be due to the fact that, depending on the business sector, many clients are unable to describe the characteristics of a desired product accurately and precisely, and it is usually up to project managers to identify and understand client needs. 
The Drive and Determination dimension could be considered the "negative highlight" of the study. Although it was the most common dimension, found in $92 \%$ of the respondents, and included leadership characteristics, it was not correlated to any of the chosen project success criteria. This finding may warrant further study for clarification.

The third focus of the analysis was verification of the existence (or nonexistence) of an association between each dimension of enterprising tendency and global Project Success Level. As shown in Table 3, Creative tendency was the only dimension significantly $(4,5 \%)$ associated with Project Success Level, confirming the correlation identified by preceding analyses although association was broken down by each of the success criteria. This correlation suggests that projects tend to be more successful when their managers have creativity as a personal characteristic.

$\begin{gathered}\text { Table 3. Association between dimensions of manager } \\
\text { enterprising tendency and project success level }\end{gathered}$
\begin{tabular}{|lll}
\hline Dimension of & Mann-Whitney U \\
Enterprising Tendency & $\mathrm{Z}$ & Asympt. Sig. \\
\hline Need for achievement & -1.260 & $20.8 \%$ \\
Need for autonomy & -0.977 & $32.9 \%$ \\
Creative tendency & -2.003 & $4.5 \%$ \\
Risk taking & -1.356 & $17.5 \%$ \\
Drive and Determination & -1.279 & $20.1 \%$ \\
\hline
\end{tabular}

However, the above interpretations are subject to the usual limitations of any behavioural study. As Pinto and Kharbanda (1995: 74) stated, several other factors are required in order for a project to have a successful outcome such as: a well-defined project mission, support from senior management, thorough scheduling and planning, client consultation, qualified personnel, technology to support the project, project acceptance on the part of the client, monitoring and feedback, channels of communication between all parties involved in the project. Many of these factors are in no way directly dependent on the project manager's effort or personal characteristics; the correlation between entrepreneurial characteristics and the success of project outcomes, however weak, is therefore relevant to the project management process.

\section{Conclusions and final considerations}

Bearing in mind that manager entrepreneurship is only one of several factors associated with project success, the present work sought to obtain evidence of whether the entrepreneurial characteristics of project managers were associated with projects that were more successful from an organizational standpoint, through a study using a 164-project sample.

Within the study sample, there was empirical evidence to support the hypothesis that the possibility of a given project having a successful outcome increases with the enterprising tendency of its manager. Correlation appeared weak in the sample, but the mere finding that such a relationship exists, on whatever level, is indicative of the importance of entrepreneurship. Therefore it may be concluded that:

- A competent project manager has several characteristics besides enterprising tendency, on which this study was focused, such as: knowledge of the project product's target area, 
interpersonal skills, an understanding of the project management context, knowledge of general management and project management practices, etc.;

- Several critical success factors actually depend very little on the project manager's actions: organizational maturity with regard to project management, clear definition of what a project is meant to accomplish, overdependence on technology, company and client expectations, sponsor commitment, adequate provision of resources required to maintain the project, etc.

Furthermore, in assessing the relationship of each entrepreneurial characteristic found in project managers with project success, the following points were observed:

-Need for achievement: was found to be positively correlated with meeting cost constraints, suggesting that managers who possess this characteristic are more concerned with project efficiency, even if they are more oriented towards the short term;

-Need for autonomy: found in a minority of project managers in the sample, on the other hand, was negatively correlated with overall contribution of the project to performance of the organization as a whole. This result is apparently representative of managers'

"shortsightedness" when it comes to broader organizational needs - project managers tend to focus on their own needs;

-Creative tendency: correlated with several success criteria across all dimensions - evidence that creative characteristics tend to influence global project performance. Consequently, projects appear to be more successful when they are led by creative managers, and success appears to increase with the degree of creative tendency;

- Calculated risk taking: a positive correlation was found between calculated risk taking and client satisfaction with the end product, indicating that risk-taking characteristics help managers create products to clients' expected specifications;

-Drive and determination: no correlation whatsoever was found with success criteria, probably because most project managers already possess the qualities associated with this dimension.

The finding of creativity as the only characteristic associated with more successful outcomes leads to the assumption that project managers must have some creative tendency to perform their duties more effectively. Creativity was not mentioned as a characteristic in the literature on project management reviewed for this study; therefore it is recommended that the profile of the project manager position be revised, so that the addition of creative tendency to the scope of a project manager's abilities may be assessed in depth. Indeed, the 21 st-century project manager can no longer be seen as a mere executor, but must be viewed as an important partner in the task of recognizing, and seeking, new opportunities. This role may require a different standard of creativity than that which has been seen in managers in the past.

Several limitations and restrictions to the scope of the conclusions must be noted, the most relevant of which may concern the respondents: the sample was solely composed of project managers. Regardless of their merits, the conclusions of this study must therefore be taken as the product of the respondents' points of view. Furthermore, the conclusions are subject to the constraints inherent to e-surveys, and should be regarded only within the context of the study sample, due to the difficulty of assessing their representativeness in the broader 
universe of projects carried out in the Brazilian business environment. Finally, it is recommended that, when considering the conclusions of this study, one does not disregard the variety of circumstances, both internal and external, of the organizations studied that would certainly affect any analyses. These issues should be addressed and, perhaps, better dealt with in future studies.

\section{References}

Andreassi, T. 2005, Empreendedorismo corporativo, GV Executivo, vol. 4, no. 3.

Archibald, R.D. 2003, Managing High-technology Programs and Projects, 3rd ed., John Wiley \& Sons, New Jersey, NY.

Antoncic, B. \& Hisrich, R.D. 2001, Intrapreneurship: construct refinement and cross-cultural validation, Journal of Business Venturing, vol. 16, 495-527.

Birley, S. \& Muzyka, D.F. (eds) 2001, Dominando os Desafios do Empreendedor, Pearson Education, São Paulo, Brazil.

Caird, S. 1991, Testing enterprising tendency of occupational groups, British Journal of Management, vol. 2, 177-183.

Carland, J.W., Hoy, F., Boulton, W.R. \& Carland, J.A.C. 1984, Differentiating entrepreneurs from small business owners: a conceptualization, Academy of Management, vol. 9, no. 2, 354-359.

Cleland, D.I. 1999, Project Leadership in Project Management: Strategic Design and Implementation, 3rd ed., McGraw-Hill, New York.

Cohen, D.J. \& Grahan, R.J. 2002, Gestão de Projetos: MBA Executivo, Campus, Rio de Janeiro, Brazil.

Cunningham, J.B. \& Lischeron, J. 1991, Defining entrepreneurship, Journal of Small Business Management, vol. 29 , no. $1,45-61$.

Crawford, J.K. \& Cabanis-Brewin, J. 2006, Optimizing Human Capital with a Strategic Project Office: Select, Train, Measure, and Reward People for Organization Success, Auerbach, Boca Raton.

Crawford, L., Hobbs, B. \& Turner, J.R. 2006, Aligning capability with strategy: categorizing projects to do the right projects and to do them right, Project Management Journal, vol. 37, no. 2, 38-50.

Dinsmore, P.C. 1992, Gerência de Programas e Projetos, Pini, São Paulo.

Dinsmore, P.C. (ed.) 1993, The AMA Handbook of Project Management, AMACOM, New York.

Hashimoto, M. 2006, Espirito Empreendedor nas Organizações: Aumentando a Competitividade através do Intraempreendedorismo, Saraiva, São Paulo, Brazil.

Heldman, K. 2003, Gestão de Projetos: Guia para o Exame Oficial do PMI, transl. Félix, T., Bookman, Rio de Janeiro, Brazil.

Hisrich, R.D. \& Peters, M.P. 1986, Establishing a new business venture unit within a firm, Journal of Business Venturing, vol. 1, no. 3, 307-322.

Jugdev, K. \& Müller, R. 2005, A retrospective look at our evolving understanding of project success, Project Management Journal, vol. 36, no. 4, 19-31.

Kerzner, H. 2001, Project Management - A Systems Approach to Planning, Scheduling, and Controlling, 7th ed., John Wiley \& Sons, Ohio.

Kerzner, H. 2003, Gestão de Projetos: as Melhores Práticas, transl. Teresa Felix, Campus, Rio de Janeiro, Brazil.

Luchsinger, V. \& Bagby, D.R. 1987, Entrepreneurship and intrapreneurship: behaviors, comparisons, and contrasts, S.A.M. Advanced Management Journal, vol. 52, no. 3, 10-13.

Lumpkin, G.T. \& Dess, G.G. 1996, Clarifying the entrepreneurial orientation construct and linking it to performance, The Academy of Management Review, vol. 21, No. 1, 135-172.

Malhotra, N. 2001, Pesquisa de Marketing: Uma Orientação Aplicada, 3rd ed., transl. Nivaldo Montigelli Jr \& Alfredo Alves de Farias, Bookman, Porto Alegre, Brazil.

Medcof, J.W. 1985, Training technologists to become managers, Research Management, vol. 18, no. 1, 18-21.

Meredith, J.R. \& Mantel Jr., S.J. 2003, Administração de Projetos: Uma Abordagem Gerencial, transl. Agliberto Alves Cierco \& Luiz Peres Zotes, LTC, Rio de Janeiro, Brazil.

Pestana, M.H. \& Gageiro, J.N. 2000, Análise de Dados para Ciências Sociais - A Complementaridade do SPSS, Silabo, Lisbon, Portugal.

Pinchot III, G. 1989, Intrapreneuring: por que você não precisa deixar a empresa para tornar-se um empreendedor, transl. Montingelli Júnior, N., Harbra, São Paulo, Brazil. 
Pinto, J. K. \& Kharbanda, O.P. 1995, Successful Projects Managers: Leading Our Team to Success, Van Nostrand Reinhold, New York.

Pinto, J.K. \& Slevin, D.P. 1988, Project success: definitions and measurement techniques, Project Management Journal, vol. 19, no. 1, 67-72.

PMI (Project Management Institute) 2002, Project Manager Competency Development (PMCD) Framework, Project Management Institute, Newton Square, PA.

PMI (Project Management Institute) 2004, PMBOK - Um Guia do Conjunto de Conhecimentos em Gerenciamento de Projetos, 3rd ed., Project Management Institute, Newton Square, PA.

Rabechini Jr., R. 2005, O Gerente de Projetos na Empresa, Atlas, São Paulo, Brazil.

Sbragia, R., Maximiano, A. \& Kruglianskas, I. 1986, O gerente de projetos: seu papel e habilidades, Revista de Administração, vol. 21, no. 3, 24-31.

Schumpeter, J.A. 1949 Economic theory and entrepreneurial history, in Research Center in Entrepreneurial History, Change and the Entrepreneur: Postulates and Patterns of Entrepreneurial History, Harvard University Press, Cambridge, MA.

Selltiz, C., Wrightsman, L.S., Cook, S.W. \& Kidder, L.H. 1987, Métodos de Pesquisa nas Relações Sociais Delineamentos de Pesquisa, 2nd ed., transl. Maria M.H. d'Oliveira \& Miriam M. Del Rey, EPU, São Paulo, Brazil.

Shenhar, A. J., Levy, O. \& Dvir, D. 1997, Mapping the dimensions of project success, Project Management Journal, vol. 28, no. 2, 5-13.

Siegel, S. \& Castellan Jr, N.J. 2006, Estatística Não-Paramétrica para as Ciências do Comportamento, 2nd ed., transl. Sara I.C. Carmona, Artmed, Porto Alegre, Brazil.

Small Enterprise Development Unit - Durham Business School 2003, General Enterprising Tendency (GET) Test, Unpublished data.

Stopford, J.M \& Baden-Fuller, C.WF. 1994, Creating corporate entrepreneurship, Strategic Management Journal, vol. 15, no. 7, 521-536.

Vasconcellos, L. \& Guedes, L.F.A. 2007, E-surveys: Vantagens e limitações dos questionários eletrônicos via internet no contexto da pesquisa científica, Paper Presented at the X Semead - Seminários em Administração Programa de Pós-Graduação em Administração, 9-10 August, FEA-USP, São Paulo, Brazil.

Verma, V.K. 1996, The Human Aspects of Project Management: Human Resources Skills for the Project Manager, vol. 2, Project Management Institute, Newton Square, PA.

\section{About the authors:}

Rosária de Fatima Segger Macri Russo is a PhD candidate of the Management Department of the Faculty of Economics, Business Administration and Accountancy of the University of São Paulo (FEA/USP), Brazil. Her research interests focus on project management, decision analysis and risk evaluation. She has an MA Degree with a major in Administration, an MBA with a major in Project Management, and a BA with a major in Data Processing, and holds a PMP Certification. She has worked in Project Management for 25 years, mainly in banks, government organisations and software houses. She teaches Project Management and Organizational Theory in graduate courses and works as a researcher in the Decide Group at FEA/USP, investigating topics related to Decision Theory applied to Project Management.

Email: rmrusso@usp.br

Roberto Sbragia is Professor at the Management Department of the Faculty of Economics, Business Administration and Accountancy of the University of São Paulo, Brazil. He has Masters and PhD in Business Administration, and has completed Post-Doctoral studies at Northwestern University, Technological Institute, Department of Industrial Engineering and Management Sciences, with emphasis on R\&D Management. He is a coordinator of the Innovation, Technology and Project Management group of Fundação Instituto de Administração, member of the Advisory Committee of the Project Management Global Forum and of the International Association of Management of Technology and Project Management Institute. He is a former President of the Latin America Association for Technology Management (1993-1997), and an author and consultant in the area of Innovation and Project Management.

Email: rsbragia@usp.br 